\title{
ANALISIS KANDUNGAN FLAVONOID PADA TEH BENALU (Dendropohtoe pentandra (L.) Miq.)
}

\author{
Jecklyn A. Lekal', Th. Watuguly² \\ ${ }^{1}$ Mahasiswa Pendidikan Biologi, FKIP Universitas Pattimura \\ ${ }^{2}$ Dosen Pendidikan Biologi, FKIP Universitas Pattimura
}

E-mail: lekal_ja@gmail.com

\begin{abstract}
Background: Benalu is one of the plant species that lives attached to other plants. The parasite is hemiparasit or half parasitic because it has a green leaf substance (chlorophyll) used for the assimilation process and only sucks water and organic matter from its host plant. Flavonoids are phenol compounds commonly found in vascular plants including parasites. Flavonoids are useful for protecting cell structures, increasing the effectiveness of vitamin C, anti-inflammation, preventing bone loss and as an antibiotic.

Method: Total flavonoid content in clove parasite tea using UV-Vis Spectrophotometer method.

Results: Total flavonoid in tea clove parasite was $0.2819 \%$. Flavonoids found in tea parasite cloves are low with the presence of heating and temperature factors.

Conclusion: Based on the quantitative test, leaf parasite is the highest flavonoid level of $13.702 \%$ and after being made tea, flavonoid levels changed to $0.281 \%$.
\end{abstract}

Keywords: Flavonoids, Benalu Tea, Biology Learning.

\begin{abstract}
Abstrak
Latar Belakang: Benalu merupakan salah satu jenis tumbuhan yang hidupnya menempel pada tumbuhan lain. Benalu bersifat hemiparasit atau setengah parasit karena memiliki zat hijau daun (klorofil) yang digunakan untuk proses asimilasi dan hanya menghisap air dan zat organik dari tanaman inangnya. Flavonoid merupakan senyawa golongan fenol yang pada umumnya banyak terdapat pada tumbuhan berpembuluh termasuk benalu. Flavonoid bermanfaat untuk melindungi struktur sel, meningkatkan efektivitas vitamin $\mathrm{C}$, antiinflamasi, mencegah keropos tulang dan sebagai antibiotik.

Metode: Total kandungan flavonoid pada teh benalu cengkih dengan menggunakan metode Spektrofotometer Uv-Vis.

Hasil: Total flavonoid yang di dapat pada teh benalu cengkih adalah $0.2819 \%$. Flavonoid yang terdapat pada teh benalu cengkih hasilnya rendah dengan adanya factor pemanasan dan suhu.

Kesimpulan: Berdasarkan uji kuantitatif, daun benalu yang paling tinggi kadar flavonoidnya yaitu $13,702 \%$ dan setelah dijadikan teh, kadar flavonoidnya berubah menjadi $0,281 \%$.
\end{abstract}

Kata Kunci: Flavonoid, Teh Benalu, Pembelajaran Biologi. 


\section{PENDAHULUAN}

Benalu merupakan salah satu jenis tumbuhan yang hidupnya menempel pada tumbuhan lain. Benalu bersifat hemiparasit atau setengah parasit karena memiliki zat hijau daun (klorofil) yang digunakan untuk proses asimilasi dan hanya menghisap air dan zat organik dari tanaman inangnya. Tumbuhan benalu sangat beranekaragam. Oleh karena itu nama dari berbagai macam jenis benalu diberikan sesuai inangnya, yaitu tempat dimana benalu itu tumbuh. Jenisjenis benalu yang umum dikenal meliputi benalu teh, benalu kelor, benalu mangga, benalu duku, benalu jeruk nipis dan benalu cengkih (Wahyuningsih, 1999).

Flavonoid dalam benalu memiliki manfaat sebagai antioksidan, antibakteri dan antikanker (Ikhawati, 2008). Oleh karena itu, flavonoid sangat bermanfaat bagi kesehatan tubuh manusia. Benalu cengkih merupakan salah satu jenis tumbuhan benalu yang hidup di pohon cengkih. Benalu cengkih digunakan sebagai bahan dasar pembuatan teh karena memiliki warna seperti teh, baunya wangi dan rasanya yang enak ketika diminum. Selain itu, benalu cengkeh mengandung flavonoid kuersetin yang berfungsi sebagai antioksidan untuk menjaga ketahanan tubuh manusia (Saraswati, 2010).

Teh merupakan salah satu minuman yang sangat populer di dunia. Selain sebagai minuman yang menyegarkan, teh telah lama di yakini memiliki khasiat bagi kesehatan tubuh. Pada masyarakat pedesaan, seduhan teh yang kental dapat digunakan dalam usaha pertolongan awal pada penderita diare. Teh juga berpotensi sebagai antimutagenetik, antihipertensi dan antitumoregenetik (Nazaruddin dan Farry, 1993).

\section{MATERI DAN METODE PENELITIAN}

Penelitian ini merupakan penelitian eksperimen laboratorium untuk menganalisis kandungan flavonoid pada teh benalu cengkih. Penelitian ini dilaksanakan di Laboratorium Biologi Dasar FKIP Universitas Pattimura untuk pembuatan teh benalu cengkih sementara analisis kandungan kandungan flavonoid dilakukan di laboratorium Kimia Dasar FMIPA Universitas Pattimura. Pelaksanaan penelitian ini dimulai dari tanggal 09 Maret sampai dengan 27 Maret 2017.

Subjek pada penelitian ini adalah benalu cengkih yang diambil secara acak dari 5 pohon yang berbeda dengan objek penelitiannya adalah teh dari benalu cengkih kering.

Tahapan penelitian dilakukan mulai dari penyiapan alat dan bahan, preparasi sampel, pembuatan teh benalu cengkih dan analisis kadar flavonoid pada teh benalu cengkih. Tahapan penelitian dilakukan mulai dari tahap persiapan dan tahap pelaksanaan.

\section{Tahap Persiapan.}

Meninjau tempat penelitian dan menyiapkan alat dan bahan yang akan digunakan dalam penelitian.

\section{Tahap Pelaksanaan}

\section{Uji Total Flavonoid Pada Benalu Cengkih}

\section{Pengolahan Sampel}

Akar, batang dan daun benalu cengkih (Dendrophthoe pentandra L. Miq) yang telah dikeringkan dilakukan pengubahan bentuk dengan cara dipotong-potong kecil, kemudian diblender hingga menjadi serbuk dan ditimbang.

\section{Ekstraksi Sampel}

Sampel akar, batang dan daun benalu yang telah menjadi serbuk, dimasukan kedalam tabung Erlenmeyer untuk dilakukan maserasi, ditambahkan pelarut metanol hingga serbuk akar, batang, dan daun benalu cengkih terendam, dibiarkan selama 7 hari.

\section{Uji Kualitatif Flavonoid}

Uji kualitatif flavonoid dilakukan dengan cara menambahkan pelarut $\mathrm{NaOH} 10 \%$ dan larutan $\mathrm{AICl} 3$ yang akan memberikan warna kuning hingga kehijauan yang menunjukan indikassi positif flavonoid.

\section{Uji Kuantitatif Flavonoid \\ Pembuatan larutan standar kuersetin}

Ditimbang sebanyak $25 \mathrm{mg}$ baku standar kuersetin dan dilarutkan dalam 25 $\mathrm{mL}$ metanol. Larutan stok dipipet sebayak 1 $\mathrm{mL}$ dan dicukupkan volumenya sampai 10 $\mathrm{mL}$ dengan metanol untuk 1000 ppm. Dipipet 
kembali $5 \mathrm{~mL}$ kemudian dicukupkan volumenya sampai $50 \mathrm{~mL}$ dengan metanol. Dari larutan standar kuersetin 100 ppm, kemudian dibuat beberapa konsentrasi yaitu 2 ppm, 4 ppm, 6 ppm, 8 ppm, dan 10 ppm. Dari masing-masing konsentrasi larutan standar kuersetin ditambahkan $3 \mathrm{~mL}$ metanol, 0,2 mL AlCl3, 0,2 mL Asam asetat qlasial, dan 5,6 mL aquades. Setelah itu diinkubasi selama 30 menit dan diukur absorbansinya pada spektrofotometer UVVisible dengan panjang gelombang 370nm.

\section{Pembuatan larutan sampel}

Kandungan flavonoid total merujuk pada prosedur Chang et al. (2002), dengan beberapa konsentrasi menggunakan kuersetin sebagai standar. Ditimbang ekstrak metanolik akar, batang dan daun benalu cengkih sebanyak $25 \mathrm{mg}$ dan dilarutkan dalam $25 \mathrm{~mL}$ methanol. Dari larutan stok dipipet sebayak $1 \mathrm{~mL}$ dan dicukupkan volumenya sampai $10 \mathrm{~mL}$ dengan metanol. Kemudian dipipet $1 \mathrm{~mL}$ dan ditambahkan $3 \mathrm{~mL}$ metanol, 0,2 mL AICl3, $0,2 \mathrm{~mL}$ asam asetat glasial, dan $5,6 \mathrm{~mL}$ aquades. Setelah itu diinkubasi selama 30 menit dan diukur absorbansinya pada spektrofotometer UV-Visible dengan panjang gelombang $370 \mathrm{~nm}$.

\section{Analisis Kandungan Flavonid Pada Teh Benalu Cengkih \\ Pembuatan Teh Benalu Cengkih}

Daun benalu cengkih yang telah kering diblender hingga menjadi serbuk dan ditimbang sebanyak 15 gram menggunakan timbangan analitik, kemudian dimasukan kedalam gelas kimia yang telah diisi air sebanyak $150 \mathrm{~mL}$. Panaskan di atas hot plate dan letakan gelas kimia yang berisi air dan serbuk daun benalu cengkih kering di atas hot plate. Setelah itu disaring dan dituangkan kedalam botol vial.

\section{Analisis Flavonoid Menggunakan Spektrofotometer.}

Sampel akan dianalisis kandungan flavonoidnya dengan cara menambahkan pelarut methanol dan larutan $\mathrm{AlCl} 3$ kemudian dimasukan kedalam chamber, amati perubahan yang terjadi dibawah sinar UV $370 \mathrm{~nm}$ dan lihat panjang gelombang atau frekuensi lawan intensitas serapan (absorbansi) yang menunjukan hasil analisis flavonoid pada penggunaan Spektofotometer UV-Vis. Flavonoid yang dianalisis dapat dihitung kadarnya menggunakan rumus perhitungan kadar flavonoid: $Y=a x+b$ dengan:

$$
\begin{array}{ll}
\mathrm{y} & =\text { nilai absorbansi } \\
\mathrm{x} & =\text { kadar flavonoid } \\
\mathrm{a}, \mathrm{b} & =\text { konsentrasi }
\end{array}
$$

\section{HASIL DAN PEMBAHASAN}

Hasil analisis jumlah kandungan flavonoid pada benalu cengkih dapat dilihat pada Tabel di bawah ini.

Tabel 1. Hasil Analisis Jumlah Kandungan Flavonoid Pada Benalu Cengkih.

\begin{tabular}{llcccc}
\hline No & Kode Sampel & $\begin{array}{c}\text { Berat } \\
\text { Sampel } \\
(\mathbf{m g})\end{array}$ & $\begin{array}{c}\text { Berat } \\
\text { Flavonoid } \\
(\mathbf{m g})\end{array}$ & $\begin{array}{c}\text { Kadar } \\
\text { Flavonoid } \\
(\%)\end{array}$ & $\begin{array}{c}\text { Rata-rata kadar } \\
\text { flavonoid (\%) }\end{array}$ \\
\hline 1 & Akar U1 & 1,0125 & 54,5 & 5,3827 & \\
2 & Akar U2 & 1,0213 & 57,5 & 5,6300 & 5,5441 \\
3 & Akar U3 & 1,0143 & 57,0 & 5,6196 & \\
4 & Batang U1 & 1,0049 & 30,5 & 3,0351 & 3,0321 \\
5 & Batang U2 & 1,0152 & 29,5 & 2,9058 & \\
6 & Batang U3 & 1,0141 & 32,0 & 3,1555 & \\
7 & Daun U1 & 1,0276 & 140 & 13,6239 & \\
8 & Daun U2 & 1,0144 & 134 & 13,2097 & \\
9 & Daun U3 & 1,0089 & 144 & 14,2729 & \\
10 & Air Rebusan U1 & 25,0334 & 68,5 & 0,2736 & \\
11 & Air Rebusan U2 & 25,1099 & 71,5 & 0,2847 & 0,2819 \\
12 & Air Rebusan U3 & 25,0303 & 72,0 & 0,2876 & \\
\hline
\end{tabular}

Data Primer, 2017. 
Berdasarkan tabel 1, hasil kadar flavonoid pada akar, batang, daun dan Air rebusan benalu cengkih di dapati rata-rata kadar flavonoid yaitu akar sebesar 5,5441, batang sebesar 3,0321, daun sebesar 13,7021, dan air rebusan sebesar 0,2819. Flavonoid pada akar lebih tinggi dibandingkan batang karena akar benalu menyerap zat hara langsung dari tanaman inangnya setelah itu diangkut dari akar ke batang melalui pembuluh kayu hingga mencapai daun. Setelah mencapai daun, sebagian dimanfaatkan oleh sel-sel daun untuk melakukan fotosintesis sehingga terjadi peningkatan senyawa flavonoid pada daun yang lebih tinggi dibandingkan flavonoid pada akar dan batang. Peningkatan flavonoid tersebut disebabkan karena daun benalu terkena cahaya langsung.

Flavonoid merupakan kelompok dari fitokimia fenolik yang berfungsi sebagai peredam radikal bebas yang sangat kuat dan membantu mencegah penyakit yang berhubungan dengan stres oksidatif, serta memiliki aktivitas antimikroba, antikorsinogen, antialergi, dan antiinflamasi. Flavonoid mempunyai sifat yang sangat khas yaitu bau yang sangat tajam, sebagian besar merupakan pigmen warna kuning, dapat larut dalam air dan pelarut organik, mudah terurai dalam temperatur tinggi (Rahmat, 2009 dalam Nimreskossu, 2016).

Benalu yang telah diambil dan dijadikan teh, di uji flavonoidnya dengan pereaksi $\mathrm{AlCl}_{3}$. Berdasarkan penelitian yang dilakukan, uji kandungan flavonoid pada benalu cengkih dan the benalu cengkih secara menyeluruh menghasilkan warna kuning.

Penggunaan $\mathrm{AlCl}_{3}$ sebagai pereaksi flavonoid dapat berlaku karena senyawa flavonoid memiliki gugus o-dihidroksi bebas. Penambahan pereaksi $\mathrm{AlCl}_{3}$ mengidentifikasi adanya senyawa flavonoid dengan ditunjukan perubahan warna menjadi kuning. Adanya flavonoid pada suatu tumbuhan akan menghasilkan hasil positif bila direaksi dengan pereaksinya yang menghasilkan perubahan warna (Gifur, 2013 dalam Nimreskossu, 2016).

Berdasarkan hasil analisis kadar flavonoid pada benalu cengkih sebagaimana ditunjukkan pada Tabel 4.2, terlihat bahwa diantara bagian akar, batang dan daun benalu cengkih, kadar flavonoid yang tertinggi adalah pada bagian daun. Akan tetapi pada air rebusan daun teh benalu cengkih mengandung kadar flavonoid yang jauh lebih rendah dibandingkan kadar flavonoid pada daun benalu cengkih. Perbedaan kadar flavonoid yang sangat jauh tersebut disebabkan karena proses perebusan yang dilakukan pada daun benalu cengkih. Proses perebusan daun dapat menurunkan kandungan kimia dari daun tanaman, salah satunya flavonoid pada daun benalu cengkih. Hal tersebut sesuai dengan penelitian Syaifuddin (2015), yang menguji aktivitas antioksidan pada bayam merah segar dan rebus, memperoleh hasil kandungan vitamin $\mathrm{C}$ pada daun bayam segar lebih tinggi dibandingkan dengan yang direbus.

Perebusan daun benalu cengkih pada proses pembuatan teh berpotensi menurunkan kadar flavonoid apalagi jika tidak memperhatikan suhu panas dan lama waktu perebusan. Hal itu dapat terjadi karena suhu dan lama waktu perebusan yang tidak diperhatikan dapat mengakibatkan terjadinya proses degradasi pada bahan yang direbus. Menurut Mastuti (2016), yang mengatakan bahwa pemanasan yang terlalu lama dan suhu yang terlalu tinggi dapat menyebabkan bahan terdegradasi sehingga menurunkan aktivitas antioksidan. Selain itu, menurut Amaliah (2007), yang mengatakan bahwa lama perebusan dapat menurunkan flavonoid. Flavonoid merupakan senyawa metabolit sekunder atau juga disebut sebagai zat antioksidan. Menurunnya aktivitas antioksidan terjadi akibat berkurangnya senyawa metabolit sekunder yang mempengaruhi aktivitas antioksidan. Proses degradasi akibat perebusan mengakibatkan dinding sel dan membran plasma cepat mengalami kerusakan, menyebabkan air masuk ke dalam dinding sel dan vakuola kemudian melarutkan senyawa metabolit sekunder ke dalam cairan pengolahan (Syaifuddin, 2015).

\section{KESIMPULAN}

Kesimpulan yang dapat diambil dalam penelitian "Analisis Kandungan Flavonoid Pada Teh Benalu Cengkih (Dendropohtoe pentandra (L.) Miq.). Berdasarkan uji 
kuantitatif, daun benalu yang paling tinggi kadar flavonoidnya yaitu 13,7021 dan setelah dijadikan teh, kadar flavonoidnya berubah menjadi 0,2819.

\section{DAFTAR PUSTAKA}

Amaliah Dahlia. 2007. Penetapan Kadar Flavonoid Total Dari Ekstrak Etanolik Daun Benalu Mangga (Dendrophthoe pentandra L. Miq).

Chang, C. C., Yang, M. H., Wen, H. M., Chern, J. C., 2002. Estimation of total flavonoid content in propolis by two complementary colorimetric methods. $J$ Food Drug Ana. 10:178-182.

Haris, M. 2011. Penentuan kadar flavonoid total dan aktivitas antioksidan dari daun beluntas (Plucea indica L). FMIPA UNSRAT Manado 95115.

Ikawati, M., Wibowo, A.E., Navista, S.O.U., \& Adelina, R. 2008. Pemanfaatan Benalu Sebagai Agen Antikanker, International Seminar of Indonesia Malaysia Update 2008, Universitas Gadjah Mada dan Universiti Sains Malaysia.
Mastuti Risna. 2016. Metabolit Sekunder dan Pertahanan Tumbuhan. MODUL. FMIPA Biologi Universitas Brawijaya.

Nazaruddin dan Farry B Paimin. 1993. Pembudidayaan dan Pengolahan Teh. Penebar Swadaya. Jakarta.

Nimreskosu, F. 2016. Uji Total Flavonoid Pada Ekstrak Tempe Daun Pepaya (Carica pepaya L.) Berdasarkan Tingkat Kematangan Daun. Skripsi. FKIP Biologi Universitas Pattimura. Ambon.

Saraswati. K. 2010. Aktivitas Antijamur Ekstrak Etanol Daun Benalu Cengkeh (Dendrophthoe pentandra (L.) Miq.) Terhadap Candida albicans Dan Trichophyton rubrum. Fakultas Farmasi Universitas Muhammadiyah Surakarta.

Syaifuddin. 2015. Uji Aktivitas Antioksidan Bayam Merah. UIN Walisongo

Wahyuningsih, M. S. H., Yustina. A. A. A . 1999. Effect of Benalu (Dendrophtoe sp.) Leaves Extract On The Male Rat (Rattus Norvegicus) Benzidine Induced Hepatotoxicity. Jurnal Kedokteran Yarsi 7 (1) : 121-132. 